\title{
Violence and chaos in Afro-Brazilian religious experience
}

La violence et le chaos dans les religions afro-brésiliennes

José Jorge de Carvalho

\section{OpenEdition}

1 Journals

\section{Electronic version}

URL: http://journals.openedition.org/span/1186

DOI: $10.4000 /$ span. 1186

ISSN: 2268-1558

\section{Publisher}

École pratique des hautes études. Sciences humaines

\section{Printed version}

Date of publication: 15 April 2004

Number of pages: 111-148

ISBN: 2-9090-3629-4

ISSN: 0294-7080

\section{Electronic reference}

José Jorge de Carvalho, «Violence and chaos in Afro-Brazilian religious experience », Systèmes de pensée en Afrique noire [Online], 16 | 2004, Online since 13 November 2013, connection on 06 May 2019. URL : http://journals.openedition.org/span/1186 ; DOI : 10.4000/span.1186 


\section{Violence and chaos in Afro- Brazilian religious experience}

\section{José Jorge de Carvalho}

Department of Anthropology University of Brasília

Sanctity calls for the complicity of being with lubricity, cruelty and mockery.

Georges Bataille, The accomplice

Violence and disorder in ritual performances tend to disturb and challenge traditional Christian values and assumptions. As in other so-called world religions, most substantive ideas pertaining to sacredness, conceived as the sphere of the absolute and the sublime, present an implicit moralizing view of religious experience seen as exclusively good, peaceful, harmonic and capable of generating only order and stability. Christianity represents the religious individual as someone who follows a path from disorder to order, from evil to benevolence, from violence to peace. Although many Western theologians, Christian practitioners and intellectuals (mostly subsequent to Nietzsche and throughout the twentieth century) have rebelled against this narrow vision, I maintain that it remains dominant in Brazilian Christianity. Moreover, most of the country's nonChristian religious movements symbolically incorporate, by way of emulation or confrontation, this conventional view of the religious sphere.

Many studies of religious practices in Brazil have shown how Kardecian Spiritualism and White Umbanda, though founded on non-Christian doctrines (reincarnation and spiritual evolution), seek to be legitimated as religions 
${ }^{1}$ For example,

C.R. Brandão (1986) has analyzed disputes for power and influence between religions in Brazil; and R. Ortiz (1978) has shown how Umbanda distinguishes itself symbolically from Macumba in a clear struggle for social and political influence. I propose understanding the deviant and « impure » side of Spiritism so as to take into account not only the sociological and political conflicts inherent in the religious field but also the complexities of the religious dimension - in the sense of a particular type of human experience - that these spirits evoke. compatible with the Christian faith. In keeping with this conciliatory pursuit, they transfer to Afro-Brazilian cults globally the task of dealing with the "lower " spirits who disturb conventions pertaining to sexual morality, symbolic purity or violent behavior. As we shall see however, certain traditional Afro-Brazilian cults (such as Shango in Recife, which I know best) discriminate, in turn, against more syncretistic cults (such as Macumba, Jurema or Pajelança), which they consider to be, unlike themselves, the depositaries of unacceptable violence and disorder.

Summarizing what others ${ }^{1}$ have extensively discussed, it would seem that such a mechanism of exclusion operates within all Brazilian religious forms. Christianity accepts violence (such as the physical trials suffered when making processions or vows) up to a point but considers excess to be unchristian. Kardecism operates identically, transferring what it deems as unacceptable to Afro-Brazilian religions in general. White Umbanda does the same. Having made alliances with Christianity and Spiritualism, it sees itself as peaceful, pure and orderly. It attributes violence and disorder to other Afro-Brazilian cults, such as Candomblé, Macumba and their equivalents (Quimbanda in particular). Candomblé and cults similar to it (Shango, Batuque, Tambor de Mina) do the same with respect to Jurema and Macumba. The latter end up being the only cults in a position to claim sacred violence and disorder as their own. I would like to consider this religious universe that openly accepts as constitutive of its own spirituality the residue rejected by others. I shall start from the two ends in this regressive chain of symbolic displacement within AfroBrazilian religious practices : Shango and Jurema.

I shall mainly refer to the Shango and Jurema cults in Recife. For readers unfamiliar with the Afro-Brazilian world, I have made a basic distinction between two cult styles. On the one hand, there are traditional cults for exclusively African deities (known as orixás or voduns). They have both a repertoire of songs in African languages and an extremely rigid, complex ritual system. This category includes Shango in Recife, Candomblé in Bahia, Batuque in Porto Alegre 
and Tambor de Mina in São Luís. On the other hand, there are cults for various supernatural entities in addition to African ones, such as caboclos, mestres, exús, pretos-velhos and pombagiras. Their songs are mainly in Portuguese; and their ritual styles, less well-defined. This category includes Umbanda (practiced throughout the country), Macumba (previously restricted to Rio de Janeiro and São Paulo but now almost undifferentiated from Umbanda), Jurema in Recife, Caboclo Candomblé in Salvador, Quimbanda in Porto Alegre and Pajelança or Cura in São Luís and Belém. Let me emphasize that this twofold distinction must be adapted to the context in each region. Ceremonies similar to those I describe as being Jurema-like (owing to their violent, evil, dark, order-subverting aspects) might be labeled as Umbanda, Quimbanda or Macumba in other studies. I intend herein not so much to provide a detailed description of existing cults as to develop a conceptual argument without forgetting, however, commonly held ethnographic norms.

First, I shall offer a selective account of a few Shango and Jurema religious ceremonies during which violent and disorderly supernatural entities possess cult members. Then, adopting a comparative perspective, I advance a theoretical model to interpret these trance situations, exploring similar body-mind states in religious traditions both within and beyond the Afro-American diaspora. My key point is that performances of this sort generate what I call a third state, beyond the structuralist ideas of symbolic inversion and antistructure commonly used in the anthropology of religion as well as other disciplines, especially through the contributions of Mary Douglas (1971) and Victor Turner (1969). In order to illustrate this idea's analytical potential, I offer an interpretation of the Dionysiac trance as described in Euripides' The Bacchae. This analysis of a cult along the margins of established power parallels the main discussion of Afro-Brazilian cults of violence and chaos. As I focus upon ritually mediated religious experience, the ideas thus developed can be seen as complementary to those presented in another theoretical essay (Carvalho, 2003). In this 
essay on the textuality and mythopoiesis of Afro-Brazilian religions, I emphasized the literary expression of marginal mysticism; herein, I shall lay emphasis on performance in this marginal mystical tradition.

\section{Symbolic polarity in the Afro-Brazilian cults in Recife}

The Shango cult, the most important religious tradition perpetuating African memory in Recife, functions as a barrier against crime and violence even though it is more widespread along the outskirts of urban areas and in the hillsides, where criminality is especially high. Like Candomblé, it centers around worshiping orixás, deities who rule over natural phenomena such as thunder, lightning, rivers or the ocean.

A prominent orixá in the Shango and Macumba cults is Exú, the messenger of the gods and a trickster capable of doing good or evil indistinctly. Since colonial times, Catholic priests have associated Exú with the Christian devil. Although the cult does not prescribe moral conduct, it does inhibit, practically and symbolically, social deviancy such as professional prostitution, immoderate alcoholism and, above all, criminal behaviour. An alcoholic or prostitute would have a hard time obeying " the law of the saint " with its countless daily rules of conduct and body control, including those applying to sexuality.

Various orixás explicitly oppose firearms. By various accounts, at least one of them (Shango) sentences to death anyone who disobeys him and becomes a thief or even a police officer. Another orixá (Ogun) protects soldiers, but requires that their violent conduct follow the profession's norms and codes. On various occasions, I have observed how well-known marginal individuals living in the Shango area where I did my research tended to peacefully coexist with the "house of the saint». They showed respect for house leaders, were cautious in dealings with them and even donated money for ceremonies. I have witnessed at 
least three cases of men " lost to the saint " because of their violent or unruly behavior. In short Melville Herskovits' classical functional interpretation, adopted by René Ribeiro (1978), though obviously insufficient, still holds : the cult as a means for promoting social adjustment.

In Recife, the Shango and Jurema cults define themselves in contrast to each other : many of their symbols are the same but bear opposite meanings. The deities called exús provide an example of this. Shango makes a distinction between baptized and pagan exús. The former accept a submissive conviviality with the orixás and are proud to be their servants or slaves. They are thought to be both subordinate and honorable, inferior and powerful. The pagan exús, on the other hand refuse conviviality with the orixás and wander threateningly through the streets causing disturbances. They inevitably end up in the hands of specialists in black magic, evil juremeiros or macumbeiros. An identical distinction applies to the eguns, ancestors who have become supernatural entities. Certain eguns (usually the deceased members of cult houses) accept to remain duly installed and regularly worshiped in the room of the dead (balé) at the back of Shango houses. However there are also disturbing, obsessive, violent, vindictive, untamed eguns who mentally unbalance "sons-of-saint". Like the pagan exús, they are invariably manipulated by unscrupulous macumbeiros or juremeiros.

During ceremonies performed for a "saint " (orixá), food is set aside in the four outer corners of the Shango house for the pagan exus and other disturbing spirits. These offerings are intended to lead these spirits to give up their intentions of invading the orixá house and breaking up the cult. Such spirits must be kept out at all costs, and the best way to do so is to establish a symbolic dialogue with them. One of the exus stationed at the entrance to the cult house offers protection from his pagan brothers, just as the room of the dead (usually located toward the back of the house) provides protection from behind. It is no exaggeration to say that the Shango house sees itself (through non-verbal but verbalizable symbols) as a temple citadel protected by 
2 « Spirits of the left» is a widespread native category referring to entities who are « heavy », " dangerous », or evil. Oddly enough, no mention is made of « spirits of the right $\gg$. a spiritual wall and surrounded from the troublesome, violent spirits who are always besieging.

Shango has always been highly ceremonial in line with a code of conduct associated with the orixás. These symbolic figures can be placed between two poles. All orixás, along with the cult's exús and eguns, have a violent, vindictive, disturbing side and demand coherence in behavior and obedience from their "sons " (a point to which I shall return). The major opposition, however, is that between the temple and the crossroads; it corresponds to a first level of delimitation between Shango and the other cult houses where spirits considered to be " low " or " to the left " ${ }^{2}$ are worshiped. From the Shango perspective, an orixá always causes less violence and disorder (and is better controlled ritually) than a "spirit ", i.e., a non-African entity of any kind. In fact, very few symbols proper to Shango allow for expressions of violence. Orixás barely speak. Unlike spirits, they never use the spoken word with its full colloquial import. An orixá normally talks like a child, in monosyllables and with an unarticulated voice. They communicate with great difficulty and complement their occasional utterances with gestures that even assiduous house members barely understand. Obscene gestures and words are absolutely forbidden, dress must be modest and animals are slain in a way that hides the bloodshed. A brief rite of ingesting raw meat is performed but in utter secrecy. Shango tends toward large-scale ceremonies characterized by well-behaved formality and self-control, in every way up to the expectations of order associated with Catholicism, Umbanda and Kardecian Spiritualism, which (also) seek to distinguish themselves from Macumba or Jurema.

Elements alluding to criminality, thus excluded from Shango's traditional symbols, enter the cult in other ways, in particular through interpersonal relations and relationships between individuals and their saints. A general aspect of everyday life in a Shango house is that its members are nearly always cursing, insulting or heaping verbal abuse on other people. They repeatedly use phrases such as cabra safado (dirty fellow), sem-vergonha (impudent, shameless) or 
frango d'uma égua (homosexual, faggot). As Yvonne Maggie Velho (1977) has found in Umbanda in Rio de Janeiro , the cults in Recife also draw on interpersonal conflicts and intrigues both inside and between cult houses. In my opinion, these intrigues are part of the religious experience.

As shown elsewhere (Carvalho, 1988), members consider that only the ancestors, great leaders in the past, have value whereas nearly all living members are involved in endless confrontations, disputes and disagreements. Not only are the qualities of human beings diminished; faults are also found in several spiritual beings. Paradoxically (given members' rigid beliefs), blasphemy against the orixas, though severely punished, is very frequent. Milder, purely exemplary punishments occur during trances: an orixá might force his son to chew nettle leaves, rub his lips forcefully on the ground or humiliate himself in front of an opponent. However this dramatized punishment must not threaten ritual order. The saint must continue dancing steadily without losing balance or body control and without exaggerated signs of suffering. Such punishments are a symbolic focus of members' religious experiences. To have been «beaten up» or «caught " by one's orixá is both a sign of great suffering and a sure reason for pride and self-assertion. It bears witness to the power of the saint, who is considered a "protector". Besides, victories and accomplishments, failures and reversals, when understood as expressions of divine will, all obviously attest to Shango's principal promise of happiness, namely direct familiarity between the person and his or her saint.

Some punishments approach sadism in their cruelty and are dreaded : saints who blind people, cut off their legs or take the lives of their sons or spouses. Such punishments are inferred after the fact. They are seen as coming out of a close relationship occuring beyond the ritual, between the son and his orixá. More than actions, they are models, sacred narratives that dramatize the orixás' power over their sons. The son will usually react to such divine violence by being more circumspect in his ritual behavior and doubling his respect, in other words, with intensified repression and 
${ }^{3}$ For an overview of Shango in Recife, see J.J. Carvalho (1990a). For a more detailed account of Jurema, see R. Vandezande (1975) and J.J. Carvalho (1990b). self-control. Late (though not too late), he will have learned the composure he lacked when blaspheming the saint and disobeying his commands.

In brief, this is what I see as the internal violence proper to Shango. Its major counterpart is ritual order, the search for a powerful, symbolic coherence. This violence strongly resembles self-flagellation in medieval Christianity, radical mystical asceticism or the Muslim muharram dedicated to Hussein : bodily suffering accepted as a desirable, moral, serious spiritual action. However outright ritual violence associated with symbolic chaos, mockery, the carnival and a destruction of polysemy is not to be found in either Shango, White Umbanda, Spiritism or Catholicism. It does occur in the Jurema cults, to which I now turn ${ }^{3}$.

\section{Symbolized violence in Jurema cults}

Jurema appears as the final stronghold, the symbolic garbage can as it were, of Afro-Brazilian religious experience and, by extension, of all Brazilian religious experience. In turn however, it is also polarized between rites presenting a coherent expression of order and ones embracing the disorderly aspects rejected by others. Let us take a look at some of these rites.

The most typical Jurema rite is mesa (table, also called catimbó), which Câmara Cascudo (1951) has elegantly described. In a sacred room with a table, where the spirits are "fixed", there are glasses, chalices and cups of various materials and colors (some antiques, others made of quality crystal), filled with water, wine or white rum. The chalices are "princes"; and the cups, "princesses». The spirits represented by these containers on the table is the "state " or " city of Jurema", a city with seven "doorways", each ruled by a spirit with great strength and healing power. The situation defined by the catimbó spirits thus represents the dominant symbolic order, as previously discussed. The fine, clear spirits of light, fixed in crystal cups and fresh water, are invoked through melodious songs, usually sung by a choir in the chapel or accompanied by a soft-sounding 
rattle (maracá). Any dancing is discreet. The congregation, dressed in white, acts solemnly and refrains from angry or vulgar words and deeds. The spirits, in turn, speak coherently. They educate, teach, heal and give advice generally based on common sense. This is Jurema's ideal : symbolic purity and a ceremony based on the models of the Catholic mass or White Table Spiritualism.

But there are several less formal sessions of consultation and healing that gather a larger audience and are scheduled at less important dates and for lesser circumstances. Of special interest are those called " of the left " (also mentioned in writings on Macumba and Umbanda). They are intended to counterbalance an evil spell or liberate people from its effects with the help of spiritual forces capable of acting against enemies or evildoers. There are also public festivals, called torés or giras (turns) or brincadeiras (games), depending on the type of entity to be worshiped. During these events, spirits might be irreverent, complain about life, make sexual innuendos, menace people threats or behave vindictively. What other Brazilian cults reject comes in evidence during these festivals. A continuum of increasing violence, obscenity and disorder extends from healing sessions (mainly those " of the left ") to the torés.

Rather than provide a detailed ethnographic account of Jurema rituals, I would like to present evidence from healing ceremonies and giras that shed light on this marginal dimension of Afro-Brazilian religious experience 4 . I shall succinctly describe a ceremony dedicated to Pombagira, a female spirit. I attended it at the Alto São José do Pinho in Recife in 1980. It presents a typical situation : a wife, whose husband had left, suspected that another woman had had a ceremony performed against her in order to take her spouse. She thus resorted to the Pombagira of a motherof-saint known for her powers with spirits of the left. In a significant coincidence, this mother-of-saint had also been recently abandoned by her lover. The mother-of-saint's and Pombagira's behaviors were dramatically self-referential; and this gave a special tone to this ceremony. The day selected for the service was Monday, Exú's day, a proper choice for works " of the left ".

\footnotetext{
${ }^{4}$ For a typology of the cults in Recife, see R. Motta (1977); and for a more detailed description of Jurema, see J.J. Carvalho (1997).
} 
${ }^{5}$ See E. de Souza's suggestive essay (1980) on the symbolic and the diabolic.
During a preliminary phase, the mother-of-saint's assistant sacrificed a chicken for the exús and performed a cleansing rite with the congregation. While doing this, the assistant chanted a long prayer asking the exús of the house to undo any evil spells cast upon the congregation and to bring peace and tranquillity, both material and spiritual, to all. During these preliminaries, before the spirits manifested themselves, figures of hate and violence, of love and peace, appeared in equal measure. But they had places in opposite fields of meaning : expressions of «the left » on one side, and expressions of peace and tranquility on the other. As the ceremony unfolded however, the field of violence was no longer tied to the moralizing, ethical principles associated with dominant forms of religiosity. A new field for expressing body-mind experience opened as violence came into its own.

The ritual work, properly speaking, was initiated when Pombagira possessed the mother-of-saint. The divinity, after dancing and transmitting a few messages, entrusted the King of Darkness, a more heavily connoted « left » spirit, with the " counter " ceremony of avenging the jilted wife so that her husband's relationship with the other woman would end in disagreement and trouble. The diabolic symbolism associated with Exú was present during this service ${ }^{5}$ : seven red and black candles, and a rooster sacrificed to Pombagira, its head yanked off by the spirit in the mother-of-saint. Seu Tranca Rua (Mr. Streetblocker), another important exú, was also summoned. Even a miniature coffin of Pombagira Mulambo (Pombagira in Rags, also " of the left ") was placed at the feet of the house's main Pombagira.

To begin the ritual, the King of Darkness blew smoke on the client and released her from the evil inflicted by her rival. Following songs related to the sacrifice, the first praise-song was sung for the spirit :

It is midnight.

All the crossroads cry :

"Where is Exú Veludo [Exú Velvet]

To solve everything now?"

Besides Exú Veludo, mention was made of Seu Tranca Rua, Exú das Almas (Exú of Souls) and Exú Caveira (Exú 
Skull). Midnight is interpreted as the point for activating the cult's " left " side : open warfare and battles, entailing active as well as reactive violence. The following song, usually sung during the ceremony's first part, also mentions nighttime :

I wish good night

to those who are of good night;

I wish good day

to those who are of good day.

This song urges people to take a position, since the spirits know full well how to handle both the peaceful (for those " of good day ") and the violent (for those " of good night »). As we shall see, the torés most serious phase, the cult of the Masters and of more violent exús started at midnight.

The following songs evinced complementary aspects that comment on, polarize, reverse and openly embrace what is seen as the negative of Christian religiosity. The following clearly reveals the trickster in Exú :

Exú has two heads.

He does his trick wherever he wants.

One head is Satan from Hell,

The other is « Streetblocker " of Faith.

When intentionally wreaking vengeance, Exú is Satan - people never accept responsibility for a gratuitous act of aggression, since it is always said to be in reaction to someone else's violence. When adopting a protective stance to ward off evil from an enemy, he is Tranca Rua (Streetblocker). In other words, we see as our protector what our enemies see as a devil who pursues them.

During the session, several songs were dedicated to Pombagira, the powerful wife of seven exús. The texts describe her as a beautiful, feminine woman, coquettish and sexually seductive, or, alternatively, as a female as dangerous and violent as Exú. In this song, praise alternates with a menace :

Little gypsy, little gypsy

With silver sandals.

She does good,

She does evil and also kills. 
The menace is even more ominous in :

Little Saint Anthony,

Tamer of wild mules.

To fool with Pombagira

Is to play with the devil.

The word devil is melodically and rhythmically stressed. Many other songs like this one associate Exú and Pombagira with the devil, for instance :

I saw a young woman in rags.

I asked who she was.

She is Pombagira Cruzeiro,

Crowned in the bale [room of the dead]

In Umbanda and in Nagô [i.e., Yoruba tradition].

She is Lucifer's wife.

Cruzeiro refers to the cross in a cemetery. In Shango and Candomblé, balé designates the house of the egun (of the spirits of the dead), which is the traditional AfroBrazilian equivalent to the Christian cemetery. This reference to the balé and the Nagô nation is intended to assert that Pombagira reigns over the whole Afro-Brazilian supernatural universe, from Macumba and Umbanda to those cults traditionally reserved for the orixás - Nagô being the best known of these, which include Candomblé, Shango and Batuque. Again, the song ends by naming the devil, Lucifer. Pombagira and the cemetery are more strongly associated in the following song :

The cemetery is a beautiful square

Where no one wants to live.

There is a white catacomb there.

That's where Pombagira lives.

These songs suggest that Pombagira is Exú's (or Lucifer's) wife. She lives in the cemetery, commands the spirits of the dead and can either help or kill human beings who approach her. It is understood that one of her major means for providing help is to kill the person's enemies. Help and revenge, protection and aggression, saving and destroying life go hand in hand in this explicit symbolism of violence.

While the sacrifice and other rites were taking place, Pombagira danced with a kitchen knife and repeatedly pointed it aggressively at her stomach. Enraged and shouting, she 
roamed around the house, knife in hand. Soon afterwards, she entered the mother-of-saint's room where she took an enormous framed picture signed by her ex-lover (who had recently left her). She threw the picture on the floor next to Pombagira Mulambo's coffin and frenetically danced on it. She then stabbed its center seven times, and dragged the broken picture to Pombagira's place. It was left there facing the wall, leaning on the trident of Exú's wife. The motherof-saint's assistant, who followed her around throughout all this, sacrificed another chicken to Pombagira and let blood drip over the picture. In a halting voice, Pombagira talked to the woman who asked for the service. She gave her advice, saying she was disappointed with the woman's conduct. She ordered her to be more determined and proud. She menaced the "man " (the client's lover) and promised to get even. Obviously, several levels of meaning were superposed. The spirit was enraged not only with the client's husband (as expected) but also with the ex-husband of her "daughter" (the mother-of-saint). Both men deserved the entity's wrath.

The client presented a mirror, which she had bought for the occasion. Pombagira looked at herself in it and ordered the woman to put it away. Soon afterwards, she protectively placed the two ends of her skirt on the woman's head. She then asked for a second skirt (Pombagira always wears large, round skirts), tore it up and entirely covered the broken picture with the tatters. Tearing the skirt up was intended to create difficulties in the man's relationship with other women, as he (both the man in the picture and the client's husband) would draw onto himself the entity's negative force. The mother-of-saint, while swinging her skirt over the woman's head and thus transmitting to her Pombagira's positive qualities (charm, self-confidence, power), threw the torn skirt over the man's picture with the intention of damning him, so that he surrender to the woman's feelings of hate and revenge and, even more, become impotent with other women.

After finishing, Pombagira left; and Master Antônio Belo, another "left" spirit, came to consolidate her work 
and protect the congregation. After him, Exú King of Darkness returned to bid farewell to all while reaffirming his role as master of ceremonies. With his departure, the « left » service came to an end.

This account describes the symbolism of violence typically expressed in "left " (religious!) rituals as performed in the majority of nontraditional Afro-Brazilian cult houses throughout the country. These rituals mostly activate dialogical symbols of inversion within the axiological sphere. By using the same mythic universe, they counteract and subvert clearly Christian symbols : Lucifer and King of Darkness are names drawn from Biblical texts.

An excellent description of such "anti-Christian" violence in Macumba is the article in a Time-Life book edited by Douglas Botting (1979) on religious cults in Rio de Janeiro. Despite its journalistic tone, the author reported a common event that, unfortunately, few studies of this area have described in depth. He depicted a cult center in northern Rio as being « disturbing, infested with the atmosphere of black magic, macabre and diabolic paraphernalia " (p. 143). He expressed his repulsion at being "present in the most unpleasant place he had ever been " (p. 144). The father-of-saint, a man he said was "suspect " and, at the same time, "charming", told him that the devil had given him the right to kill, that he kept five thousand dead spirits in his egun house and that he worked for evil along with Exú Tiriri. This sensationalistic, stereotyped article reproduces precisely - but without providing any interpretation or adequate context - the type of discourse used by Jurema and Macumba leaders when working for the "left. » They want to frighten, shock and instil fear by means that are already part of prevailing imagery.

My principal objection to articles such as the foregoing is that they forget, or are unaware, that « left » work, however frequent and long it might be, is but an aspect, or moment, in a religious practice that also accepts peacefulness and kindness. There is always a dialogue between these qualities, as seen at the start of the aforementioned session. Even 
the cemetery, a symbol very present in the "left " world, is frightening only because of the meaning already attributed to it by Christianity : an association with danger, nightmares, negativity and death. Macumba ceremonies tend to play with the violence generated by the terror and fear that have been previously instilled, usually by the Catholic Church.

Another father-of-saint in Recife, while showing me his altar for Tata Caveira (Old Father Skull), told me that he really liked to perform works of evil, use " heavy " exús, gather soil from cemeteries or nails from coffins, and place people's names in dead horses' mouths. The Christian language of violence is widely used to arouse terror and refer to diabolical actions. Despite this, few scholars have commented on these aspects of Brazilian religiosity.

Other examples, in Umbanda, of this " constitutive " violence mainly operate on the borderline between interpersonal conflicts and subjective feelings. Y.M. Velho's book (1977) on orixá warfare has analyzed symbolic and physical aggression between cult members. She mentions various images associated with this violence within AfroBrazilian religiosity. For instance, during a "demand" (a war), a person stabbed a $15-\mathrm{cm}$. knife that belonged to his Preto Velho (Old Black Man spirit) into his own chest (p. 76). Y.M. Velho also mentions a trial by fire (prova de fogo) during which a member puts his hand in boiling palm oil or drinks white rum set ablaze in order to prove whether he was really "with the saint ", i.e., possessed (p. 75) ${ }^{6}$.

We have apparently reached the borderline between symbolic and literal - albeit controlled - violence. This very borderline arouses ambiguous feelings toward AfroBrazilian cults, ranging from prejudice and repulsion to fascination and exaltation. We need but recall the many publications that have highlighted initiation and animal sacrifices in Candomblé by showing images of wounds and bloody heads. Henri Clouzot (1951) inaugurated this sensationalistic approach when he displayed the first photos of a daughter-of-saint (probably in trance) with a beheaded chicken's neck in her mouth. Pierre Verger (1954), too, has
6 Y.M. Velho (1984 : 164) has described other aspects of this violence : «I always worked in a universe of research where the mediums go into "violent" trances and are possessed by spirits that roll on glass shards, cut themselves $[\ldots]$ »). 
${ }^{7}$ In Orishas (1981), a revised edition of Dieux d'Afrique, P. Verger omitted this sensational series. No explanation was given, and I wonder who made the decision to omit it, whether the author himself or his Brazilian editor.

${ }^{8}$ From an academic viewpoint, it would be worthwhile, even urgent, to follow up on the handling of some of the photos taken by P. Verger of the Candomblé in Bahia. To take but one example : under the general heading of « Voodoo », photo no. 15 in his Orishas (1981) has been reproduced in G. Bataille's L'érotisme (1957), in M. Surya's (1987) study of G. Bataille's writings and on the cover of the Spanish edition of A. Métraux's (1963) classic on Haitian voodoo. Furthermore, photos from the original edition of

A. Métraux's Le vaudou haïtien (1958) appear in G. Bataille's The tears of Eros (1989).

${ }^{9}$ Photos like those in the aforementioned works by P. Verger or D. Botting are mainly viewed by persons who do not belong to these cults. Most of these viewers' aesthetic and spiritual feelings have been shaped in a Christian environment. These images have a different impact on members of Shango or Candomblé. They present to public view pictures of secret, restricted events, wherein participation is a matter of initiation or merit. On the significance of showing these secret Afro-Brazilian rites, see J.J. Carvalho, 1988. published an impressive series of photographs that, taken in Yorubaland, show a group of men in trance, shredding dogs to pieces with their teeth in an offering to the orixás ${ }^{7}$. This portrayal of violence has continued in, for example, the startling photographs in D. Botting (1979) of exús and Pombagiras and of a woman initiate with a shaved and bloody head. The intention behind a photograph in Ernesto La Porta's book (1979) is even more ambiguous : a mother-of-saint dances in a trance with a sacrificed ox's head on her head. The author's orthodox psychoanalytical approach, while apparently rejecting and exorcizing this sort of worship, nonetheless clings to it with an undeniable fascination with this "primitive ", almost " psychotic " world. In any case, Afro-Brazilian imagery continues to attract many people both in- and outside Brazil ${ }^{8}$.

What does this endlessly repetitive, literary and visual, reproduction of imagery indicate? Does it simply reflect curiosity about exotic and primitive customs of whatever sort? Such scenes of religious violence fascinated authors like René Girard and Georges Bataille, who saw them as a vestige, an unconscious link with the archaic theme of sacrifice so intensely debated in religious writings. I would argue that this imagery also suggests a violence that is full both of potential and of threats, especially since it uses the symbolism of fresh blood, a primary symbol of life and of the ending of life. Its attraction might derive from the very fact that these images are wrapped in the seemingly protective clothing of religious rites and, therefore, express a contact with the divinity, who is never fully under control. Violence has a place in this gap, in the active pause of the religious event, for which moral thinking is unable to account by using standard justifications. Its presence causes a major misunderstanding that not only calls for interpretation - forcing an opening in traditional Christian hermeneutics - but also invites observers to consider a facet of this god that is quite distant from any summum bonum ${ }^{9}$.

What fascinates people is, in my opinion, that these images are accepted as religious while being labeled as exotic. The Catholic paradigms of transubstantiation, of the growing abstraction or dematerialization of the sacred, 
of the supremacy of ideas over the senses, and of repressive pacifism - in brief, the growing " angelization " of religious experience lamented by Allen Tate (1952) - comes face to face with another religious paradigm proposing the exact opposite : an emphasis on the sacredness of living blood, of animal death, of what pollutes and repulses. This « antiaesthetics " of body and gesture entails an ethics that is concrete and circumstantial rather than abstract, personal rather than universal, vindictive (when necessary) rather than peaceful ${ }^{10}$.

\section{The symbolic and the literal}

Another typical example of this radical ritual violence is what the Brazilian press has called the " Pombagira case ". It involves a woman who, while following the orders of the spirit Maria Padilha, killed a businessman. Márcia Contins and Márcio Goldman (1984), who studied this crime, mainly intended to analyze the interplay between the discourses of the criminals, sheriffs, judges, medium, Umbanda leader, etc. Referring to Foucault, their model of analysis draws attention, above all, to the political conflict between social institutions. I think this analysis must be completed by taking into account a further essential factor, namely : the crime was based on a religious experience. A spirit, who possessed the woman at police headquarters, gave the fatal order. This rather usual religious experience determined the course of events and made this story interesting.

In most cases, we observe the execution of a metaphorical murder; and this distance between "signifier" and " signified " (in other words, Frazer's "sympathetic " magic) is the essence of " left » work, as described in the preceding section. The Pombagira case fascinates because the violence associated with Macumba spirits was actually performed. After so many songs affirming that Pombagira " does good, does evil, and also kills ", the spirit apparently incited a real murder! The imagery joins up with reality, and the distance between signifier and signified, which normally sustains the religious field's relative autonomy, disappears ${ }^{11}$.

\footnotetext{
${ }^{10}$ For a thorough discussion of ethics in Shango and Afro-Brazilian cults in general, see R. Segato (1995).

${ }^{11}$ R. Segato (1991) has suggestively written about this continual passing from the symbolic to the literal in association with violent Afro-Brazilian entities.
} 
12 Two sacrificial child murders under macabre circumstances created an emotional reaction in the country in 1992, one in Guapó (Goiás) and the other in Guaratuba (Paraná). The press qualified them as « black magic rituals ». In both cases, exús were said to have demanded the children's blood. See «"Bruxo" é preso por crime satânico ॥, Folha de São Paulo (4July 1992) and « Pai-de-santo encomendou o sangue de uma virgem para usar em um trabalho de Macumba », O Popular (29 May 1992). In late December, the murder of a soap opera actress was also immediately set down to black magic. The main suspect allegedly had a statuette of Pai Chico (Father Francis, a pretos-velhos spirit). See « Evidências reforçam tese de magia negra », Jornal de Brasília (3 January 1993).
As in many cultural and religious traditions, a continuity runs between symbolic and literal violence, between the "left " ceremony I witnessed in Recife and the Pombagira case. Let us recall, for example, the goddess Kali and her oriental equivalents, as well as the symbolism of violence and death that exerts fascination in the West (Bataille, 1969). Whereas law condemns murder, religion does not always do so, as Walter Benjamin (1986) has pointed out with regard to Judaism. Indeed, countless religious traditions have resorted to human sacrifice : the Aztecs, Nepalese and, till recently, the Ashanti and Yoruba. Despite all this, we should not overlook profound differences. Human beings were sacrificed to Huitzilopochtli in response to a predictable, symbolic requirement for achieving collective well-being (if only of the Aztec ruling class), whereas the businessman's death in the present case corresponded to an extraordinary, atypical command given by Maria Padilha to settle an interpersonal conflict. On one level however, these two situations are alike : Maria Padilha, who normally sublimates the literal violence present in Afro-Brazilian gods (as in Aztec divinities), can sometimes do exactly what the latter did : she can cause a human being to be actually killed ${ }^{12}$.

Until now, I have sought to draw attention to the violence constitutive of Afro-Brazilian notions related to the sacred sphere. This violence does not occur in isolation however. It fits into a broader phenomenon that, seen from a conventional Christian viewpoint, might be called " antireligiosity", which entails vulgarity, explicit sexuality and even obscenity. To examine this, let us return to the «left " ceremony in Recife.

\section{From violence to obscenity}

When the work ordered by Pombagira was over, a few people (including myself) who stayed behind went into the main room of the mother-of-saint's principal house to have a light lunch. The long, intense session had visibly exhausted the mother-of-saint. Suddenly, while we were relaxing 
around the table, an entity called Mistress Ritinha possessed her and openly invited me to have sexual relations with her. I politely declined with the help of the others, who discussed matters with the entity and persuaded her to give up the idea. She finally agreed to go away and leave me alone but not without first expressing her desire in a deliberate and obscene manner. Many women told me that the mother-of-saint was used to being possessed during ceremonies by this particular Mistress Ritinha, who would seduce someone from the public or circle of initiates. She and her partners would leave the temple to have sex, the man in an ordinary state of mind and the mother-of-saint possessed by the spirit. When doing this, Mistress Ritinha always left an unmistakable mark of her presence : the next day, the man's penis would be covered with spots that lasted for several days.

Although the story of Mistress Ritinha seems, at the very least, odd with respect to social conventions, countless sexual transgressions (to use G. Bataille's classic term) occur during Jurema ceremonies, especially public ones. During one performance, I observed two women, the one possessed by a cowboy and the other by a mistress of the Ritinha type, dance holding each other in an intense, obviously amorous embrace for a long time. There was also a caboclo spirit (part white and part Indian) who, when possessing a woman, tried to leave her naked; here, the spirit's erotic, if not directly sexual, intentions should not be overlooked. I have also heard of cases when an entity, indwelling a man, asked to " pee ", and another man goes to help him in a clear dramatization of homosexual relations. Besides all this, it very often happens that men and women who, having received Mistress and Pombagira sprits (most of whom define themselves as spirits of prostitutes), try to seduce participants during ceremonies. A few authors ${ }^{13}$ have hinted at such behavior; discussions of it risk, of course, falling into sensationalism or ethnocentric exoticism.

Such behavior must be understood as part of cult members' ritual practices. It must be better understood because it forces us to look beyond moralizing notions of

\footnotetext{
13 In his study of Umbanda in São Paulo, R. Ortiz (1978: 130) has stated that, during the cults to exús, « the content of man-god conversations is highly sexual ».
} 
sacredness and religious experience. Rather than serving as a model for good behavior or an act of contrition or repression (implying an acceptance of and obedience to order), this sort of religious act corresponds to a social and individual sphere where limits expand and are transgressed. Through obscenity, a shift is made; and a new, meaningful space opens where the body, its propensities, tendencies, desires and truths are asserted and made sacred, contrary to the prevailing Christian world-view and morality, which denies them. This new space, precisely because it is framed within the ritualized field ruled by spirits, can emerge beyond censorship and guilt feelings. In other words, the religious act generates a new state of being that maintains the ceremony's promise of happiness while transgressing it.

Jurema and Macumba, as privileged places where this marginalized power comes into play, sometimes accept such a degree of forbidden freedom that a merely symbolic inversion shifts so far as to point toward a state of chaos. I would like to show this through a few ethnographic sketches.

\section{Symbolic inversion, the unclean and the grotesque}

I have mentioned forms of violence and obscenity observed during a private service for settling interpersonal conflicts. Before drawing general conclusions, let me briefly describe a public Jurema festival (toré) even more distant from a symbolism of purity and order.

This ceremony starts like the previously described "left" service. During offerings of food to the entities, a caboclos, mestres, exús or pretos-velhos spirit possesses the cult house leader and takes a direct part in animal sacrifices. It nearly always tears off the heads of a pair of doves with its teeth. This act frontally attacks the Christian association (familiar to most Brazilians) of doves with peace, gentleness, the most subtle aspect of divinity and a delicacy to be protected. It opens a new range of meanings for this sacrifice, which is seen as an extreme act of violence from a Christian point of view. 
The public ceremony following the sacrifice divides into two parts. The first always starts with the manifestation of an exú, followed by caboclos, pretos-velhos and orixás (including Ogun, Oxóssi and Iansã). These spirits always bring on a trance «lighter " than what will occur during the second part of the ceremony. Some of them are playful, childish, clumsy, sullen or even "wild " but without being disrespectful toward each other, their "horses " (the possessed) or the congregation. Already during this first, calmer part of the Jurema ceremony, the collective pressure for formal order is much less strong than during a Shango ceremony for orixás, where many levels of formality come into play. Fixed codes govern each orixá's trance, its way of dancing, gesticulating and transmitting messages; there is a fairly rigid sequence of songs, a precise polyrhythmic performance by the drummers; and the dancers are faultlessly dressed. Moreover, nearly inescapable temporal and spatial protocols regulate the tiniest details. Cleanliness, order, elegance and aesthetics are fundamental to a Shango celebration, while a toré is more freely improvised.

The first part of the celebration always ends at about midnight. During this mandatory intermission, a drink called jurema (made from the jurema tree's inner bark, honey and sugarcane rum, cachaça), is distributed to the congregation, first to the men, then to the women. All the men then kneel in a circle in the center of the main room with the women standing behind them.

The following song marks the start of the second part of the ceremony :

Master lords of the other world,

Of the other world and this one too,

Give me permission to save

Master Carlos/Seu Zé Pelintra/Exú das Trevas/etc.

[Mr. Joseph Scoundrel/Exú of Darkness/etc.]

In the hours of God. Amen ${ }^{14}$.

When the celebration resumes with the Masters (the group of entities that best characterizes Jurema), the previous, fragile ritual order simply vanishes. The dance circle was broken since the caboclos appearance during the ceremony's first part, and it now no longer seems to exist.

14 This song is symbolically equivalent to the song during the «l left » service : «It is midnight/ All the crossroads cry,... » 
15 O.J. Trindade-Serra's (1981) excellent analysis of the behavior of erês (childish spirits or childish aspects of the orixás) in traditional Candomblé in Bahia highlights the structural role of impurity and " dirtiness ». According to a personal communication from Mundicarmo Ferreti, certain erês of lansã in Tambor de Mina do Maranhão eat chicken droppings. Norton Figueiredo also told me about a custom, practiced in Batuque ceremonies in Porto Alegre, of eating the maggots that breed in the meat offered to the orixás after it has laid at the saints' feet for three days.

${ }^{16}$ M. Bakhtin (1984: 115) explains Menippean satire as : «The adventures of truth on earth take place on the high road, in brothels, in the dens of thieves, in taverns, marketplaces, prisons, in the erotic orgies of secret cults, and so forth. The idea here fears no slum, is not afraid of any of life's filth. »

\footnotetext{
17 Remember that, to a degree, Shango and Jurema share the same clientele. In a majority of cases, the person who receives an orixá in a Shango ceremony and dances, for example, as Iemanjá or Orixálá with dignity and majesty will also, at another time, take part in a gira where he/she is possessed by grotesque, violent, obscene or unbalanced spirits. The political and symbolic polarization between these two styles of trance has an internal, psychological and individual counterpart.
}

The sprits move about anarchically, drinking and spilling drinks on the floor, yelling, gesticulating, and uttering incomprehensible words to each other and to people. In a Jurema celebration I attended, an entity went to the kitchen, grabbed a piece of cold cooked beef out of a pan and brought it back into the room. After throwing it on the ground, chewing and cutting it into pieces, she offered it to all those present, ordering them to eat it. They did so, since the meat was a gift from a supernatural entity who promised to help and protect them. Another entity, grabbing a bunch of bananas from the offering room, peeled them, mashed them carelessly with his hands and then distributed the mashed results (which had repeatedly fallen on the ground) to be eaten. Another entity forced the woman it possessed to look for « little bugs to eat " (cockroaches) on the floor. An acquaintance of the woman tried to change its mind, moving the woman away from where there were cockroaches; and the entity grudgingly accepted. During such celebrations, countless instances of "impure", dirty behavior occur that seem to parody the actions of preparing and serving food ${ }^{15}$. This sharply contrasts with the offerings made to orixás and other spirits, which are the most sacred and ordered act in traditional Candomblé and the refined services of Table Jurema.

The high degree of dramatization in the trances of Masters and Mistresses suggests a parallel between AfroBrazilian cults and the Zar cult in Ethiopia, as analyzed by Michel Leiris (1958). During these torés (sometimes called brincadeiras, "funny games "), the carnival-like inversion of the seriousness of other Afro-Brazilian ceremonies is reminiscent of the expressive style of Menippean satire, which Mikhail Bakhtin ${ }^{16}$ (1984: 115) interpreted as an unusual combination "of the mystical-religious element with an extreme and (from our point of view) crude slum naturalism ». The toré is, indeed, a religious ceremony that satirizes another ritual with which it has strong historical, sociological and economic affinities ${ }^{17}$.

It does not suffice, however, to point to this obvious symbolic inversion, to construe Jurema merely as a parody 
- a type of Batracomiomachia - of Shango and to liken it to certain grotesque passages in the Iliad and Odyssey ${ }^{18}$. Quite to the contrary, from the viewpoint of the entities involved, a serious game is taking place in the guise of childish play. A spirit who performs buffooneries is also capable of transmitting positive messages, of curing, protecting, punishing or wreaking vengeance on enemies. From the perspective of the celebration as a whole however, there are so many spirits, and their behavior is so varied that confusion reigns. Lewd, obscene, witty, challenging, frightening entities utter incomprehensible words, scream, whisper, shake and dance in a disorderly manner or wander about in a semicataleptic state, leaving the room or mingling with the congregation, etc. Anarchy in the conduct of the ceremony, spatial disorder and disregard for chronology - unknown entities appear at any moment - increase the ceremony's entropy. An aesthetic counterpart to this confusing "hierophany" is the disordered music. The drums and melody are not synchronized, and songs do not receive the correct response or are whimsically sung together with, as a consequence, a peculiar cacophony. At its start, the toré was already quite relaxed; now the impression borders on utter chaos.

\section{From inversion and antistructure to symbolic chaos}

Impurity and the transgression of limits are not complete but come close to being so. Although complete symbolic disorder is not quite attained, we are given the experience of the possibility of an evanescent symbolism of chaos. Some " heavy " exús appear at this point. They usually frighten onlookers through the distorted faces and bodies of the persons they possess. They thus make participants aware of the presence of a monstrous devil, a far cry from the affable trickster whom many authors see in Exú ${ }^{19}$. This part of the ceremony evinces the principle of anarchy. Every entity has an autonomous behavior and obeys only whom it chooses. The cult house leaders cannot exercise censorship or administer severe admonitions. This state of affairs lasts

\footnotetext{
18 These Homeric poems narrate, in a burlesque form, interventions by the gods in a not very heroic war between mice and frogs.

19 The « heavy » exús bring into action an expressive dimension seldom found in other religious ceremonies in Brazil, namely the grotesque, not as something comical or buffoon but with its principal meaning according to Victor Hugo (no date) : playing with the horrible, the deformed.
} 
for three or four hours, until the celebration comes to an end with a rite to an exú and a song during which everyone embraces and holds hands before returning, tired, hungry and sleepy, to the everyday, structured world. This is the religious environment of a typical Jurema celebration in Recife.

An analogous example comes from a Macumba service in Rio de Janeiro, which has been reported in a scarcely known, undated book by Harnett Stoutjesdijk and George Glaser. Besides the photos of exus rolling over glass shards and drinking animal blood, the authors present pictures of a spirit called Exú Porco (Pig), who fills his mouth with cachaça, grabs a frog and spits the draught directly into its opened mouth. He then dances holding the frog with his lips in what resembles a diabolical, drunken interspecies kiss.

What conceptual model should we use to make sense of such situations? Our first impulse is to relate these rites to ideas of liminality, antistructure or communitas as developed by Turner. However I fail to see how the effervescence of communitas or of Martin Buber's mythical I-Thou relationship (to which Turner often refers in speaking about religious liminality) comes into play during this pandemonium. Exú Porco ends up setting fire to the drunk frog! The notion of antistructure (Turner, 1969 : chapter 3) may well apply to the foregoing examples, such as the distinction between the pagan and the baptized exus, or the Bakhtinian carnival-like aspect during the first part of the Jurema ceremony. In his later works, Turner stated that, even though the concept has been understood in this way, his use of the term antistructure refers to neither a structural reversal nor a mirror image of a "profane", everyday socioeconomic structure. Instead, what he meant was the «liberation of human capacities of cognition, affect, volition, creativity, etc. » (1982 : 44). Despite this undeniable intellectual openness on the part of someone deeply influenced by structuralism, Turner still, it seems to me, saw only the centripetal, community-oriented, positive side of this liberation, and not, as I am proposing, its explosive, centrifugal, negative, 
even violent side. Indeed, the symbolism of Masters and " heavy " exús is related more to unpredictability and disorder than to a clear polarization between pagan and baptized conduct, or between playfulness and seriousness.

To clarify the frame of meaning under discussion, let us briefly visit a witch's kitchen as described in a well-known scene out of Goethe's Faust I. There, a classical symbolic inversion is described. Using a goblet and a big kettle, the witch prepares an « anti-soup " with ingredients (lizards, bat wings, etc.) that are " anti-food». She treats what is not food like food and makes a new (diabolic) soup. She offers it to whoever wants to take part in her banquet. In contrast, the supernatural entities I have mentioned use any ingredient (food or anti-food), refuse the differentiation between what is raw and what is cooked, do away with etiquette, etc. They subvert the principles of ordinary cooking and gastronomic order but without proposing an alternative order.

Behavior like that of Exú Pig or of the spirit who likes to eat cockroaches makes Shango (which is already highly orgiastic when compared with Christian services, Kardecism or Umbanda) look constrained and self-controlled, i.e., Apollonian! To further the understanding of this passage from Afro-Brazilian ceremonies, by way of an antistructure, to the unstructured world of «left " spirits, I would like to draw a brief comparison with the religious world of Dionysus, as portrayed in the fascinating text of Euripides' The Bacchae. This last digression will enable me to outline a broader theory for interpreting the type of religious experience I have been describing.

\section{Dionysian disorder}

The Jurema and Macumba spirits behave very much like the Maenads. The Bacchae foregrounds a clear division between a cultural (or social) order and a natural order. The city of Thebes was founded by Cadmus, the civilizer, whose life depicts the transition from bestiality to humanity. $\mathrm{He}$ 
slew the dragon that guarded Ares' spring and sowed its teeth, which grew into the Sparti, the future men. When the play starts, Pentheus, Cadmus' grandson, is ruling Thebes. He perpetuates an extremely rigid social order that is especially hostile and repressive toward women. Thebes sees itself as a fortress resisting the march of Dionysus, who has come from the fields of Phrygia and is converting women to make them part of his followers, the Bacchae. Pentheus' mother along with his sister and many others have abandoned Thebes and gone to Mount Cithaeron where they perform Bacchic rites. Let us focus on the central part of this story when Pentheus receives a messenger who describes these extraordinary celebrations.

At the start of his report, the messenger enthusiastically provides a romantic account of the differentiation between nature and culture. On Mount Cithaeron, the women sing, dance and nurse goats along creek banks. They touch rocks, and crystal-clear water wells up. They plough the soil with spikenard, and a fountain of fresh wine starts flowing. The city and civilization are founded on repression, discipline and control over « natural » inclinations. Culture is orderly, each thing having its place. Coercion is the price paid for this. In contrast, Mount Cithaeron is a bucolic, pastoral ideal of nature seen as being orderly, fertile, pleasant, peaceful and free. By living in harmony with animal and plant life, human beings provide evidence pointing toward an earlier perfect plan. The Theban women - freed from domination by men (bear in mind that Pentheus wants to enslave them again) and content with the god who makes them happy - contribute, through their miracles, to turning Mount Cithaeron into a positive image of nature as a sort of Eden.

Till this point, the play presents a structural opposition that, formulated in Lévi-Straussian terms, shows the same logic operating in the natural and cultural orders. The transformation from one order to the other hinges on the familiar transition between repression and liberation, which Turner (1975) theorized in his study of « social dramas ": 


\begin{tabular}{|l|l|}
\hline Thebes & Mount Cithaeron \\
\hline culture & nature \\
\hline repression by law & liberation by law \\
\hline negative & positive \\
\hline male & female \\
\hline $\begin{array}{l}\text { divergence from } \\
\text { the animal world }\end{array}$ & $\begin{array}{l}\text { identification with } \\
\text { the animal world }\end{array}$ \\
\hline
\end{tabular}

This classic structural model seems to accurately reflect the essence of Cithaeron as a place of song and orgiastic dancing reserved for women.

However, as soon as the Maenads discover that men in hiding are watching them, they start acting differently. What the messenger now describes is no longer humankind in harmony with nature but rather madness and confusion, which closely resembles the violence and disorder we have seen at work in Jurema. The women slaughter pregnant cows, eat the meat raw and tear furious bulls into bits and pieces. This imagery is not limited to the animal world : the women also attack villages and kill children, adults and animals. This chaotic, destructive state of trance, so different from the previous magical trance when the women performed miracles, points, in my opinion, to a body-mind state beyond (or away from) the states of structure and antistructure. This « third state » is fully embodied, but it is also a state of consciousness, an utter confusion of categories, where the logic no longer (or not yet) applies that is supposed to generate stable forms and transformations in both nature and culture. This third state, generated (or at least implied or pointed to) by certain ritual performances, crops up as an essentially arbitrary human dimension. It does not reflect our conception of natural behavior, because nature is patterned, predictable schemata, like instincts. Nor does it qualify as being fully « cultural ", since we conceive of culture as a mechanism for producing adjustments or conformity to a valued conceptual order with limits that, though intrinsically arbitrary, are well marked in every situation and thus provide the grounds for the emergence of stable, inter-subjective symbols ${ }^{20}$.

${ }^{20}$ Drawing on E. Dodds (1960), E. de Souza (1974), G. Kirk (1979), W. Otto (1981) and C. Segal (1982), I have proposed a personal interpretation of this particular dilemma in The Bacchae. I hope to develop elsewhere this brief sketch of the relation between certain Afro-Brazilian cults and the Dionysian universe. In line with my previous emphasis on the basically metaphorical violence in Macumba, we would have to consider that the differences in behavior between Jurema spirits and the Maenads are a consequence of conventions specific to two quite distinct modes of expression : rites of reversion and disorder, on the one hand, and, on the other, the written text of an ancient tragedy. 
The Maenads raise problems similar to the ones previously discussed about the limits of applying the idea of an inversion. Each small aspect of individual behavior in this third state might conceivably be reduced to an instance of inverse symbolism, to a sort of antisymbolism that would simply deny the established order. The thus obtained progression would extend from eating cooked meat (cut and prepared according to Theban customs) to sparagmos (violently tearing apart a live animal) and omophagia (the "chewing of pulsating meat ", as Eudoro de Souza puts it), from the women protecting infants to them killing children, from amorous relations with men to persecuting and slaying them, and so forth. However this mere inversion of meanings does not account for the intensity of the arbitrary, particularizing disorder of this third state, which, I believe, has more to do with a presymbolic (and, therefore, chaotic) manifestation of human experience. It is this pre-representational state - a consequence of a real, albeit accidental, transgression of symbolic conventions - that separates cultural from natural behavior, as Euripides suggests. As E. de Souza (1974 : 100) has stated, « Dionysus transfigured the mountain into a nature that does not know man and in which man does not recognize himself. "

\section{Breaking the limits}

Both Jurema rites and Euripides' tragedy point to the common tendency in our analytical thinking to contrast nature with culture and load these categories with values that are alternatively identical, equivalent, polar or antagonistic depending on our own particular morality. In some cases (as under the Freudian conceptual model), societal order is seen as good and defensible; to be civilized is to remove oneself as far as possible from a "natural " state of being. In other cases (such as the Rousseauistic ideal), social order is seen as imprisoning, repressing human potential. The argument for this view invokes a natural order distinct from and supposedly pre-existent to human nature. Between these two extremes lie several models that posit 
a moral continuum from nature to society and search to identify the exact moment when the totally human individual emerges.

Despite these attempts (mainly based on utopian visions) to define a continuous series of states of being, human symbolism frequently reacts against this ever present possibility of a gap between nature and culture, a separation nearly always felt to be painful (as the many variants on the myth of the fall from paradise express). A third state thus emerges as a refuge, a both promising and threatening reminder that becoming human is always an incomplete process, a state yet to be attained. To become civilized is to opt for one of the poles in the opposition constantly regenerated by the mind; and this always implies closing off certain possibilities of being. This chaotic third state might, therefore, operate as a founding element, a generator of ever new limits for the process of order (be it structural or antistructural), symbolic conscience, civilization and the ways this process disciplines and frames bodily experiences. Furthermore, it creates an opportunity, perhaps fleeting, to face extreme otherness, to meet the totally other ${ }^{21}$. This state, I suggest, is activated through religious practices, such as trance, that least separate body from mind. The unity of body and mind is so apparent during trances that describing a trance as an altered state of consciousness turns out to be inadequate since a trance is also an altered state of body.

Euripides' tragedy raises what E. de Souza (1974: 11) calls the "problem of Classical Greece " : "In its twilight hour, looking inward, [it] shivers in amazement at discovering that the spirit - disciplining will and ordering intelligence - is unable to annihilate all elementary irrationality without destroying, through this same act, its very reason for being. " In this highly significant context, Tiresias, an incarnation of Apollonian knowledge (métron), accepts the need to worship Dionysus, the barbarian god who comes to literally "decivilize " Thebes. He apparently wants to remind us that we always return to culture after a period of chaos and that it is, therefore, important not to resist giving in to disorder. As the end of the tragedy shows
${ }^{21}$ A similar discussion figures in J.P. Vernant's brilliant essay on the Gorgon's mask. The Gorgon was an attempt to « give shape to this experience of an absolutely other; that which manifests itself, in its relationship with the human being, as difference : instead of the other man, the man as other $\gg$ (Vernant, 1988: 35). 
22 See the section « From religious sacrifice to the erotic » in G. Bataille (1957). (when Agave discovers she has cut her dear son's head off), a high price is paid not only for repression but also for a prolonged chaotic trance, a state of consciousness that does not allow for the protective discernment of shared consciousness. Nonetheless, the fleeting experience of this pre-representational state enriches the human spirit, since it gives a glimpse from outside of conventions while avoiding crossing over into the dangers of madness or uncontrollable states of unconsciousness.

We are thus led to propose a schema for interpreting Euripides' tragedy as a text pointing to a radical symbolic dissolution analogous to what happens during the postmidnight Jurema ceremony :

\begin{tabular}{|l|l|l|}
\hline Structure & Structural Inversion & Third State \\
\hline Thebes & $\begin{array}{l}\text { Peaceful Mount } \\
\text { Cithaeron }\end{array}$ & $\begin{array}{l}\text { Mount Cithaeron after } \\
\text { the Maenads' frenzy }\end{array}$ \\
\hline Male order & Female order & Generic disorder \\
\hline Ceremonial rigor & $\begin{array}{l}\text { Satire and } \\
\text { «carnivalization » }\end{array}$ & $\begin{array}{l}\text { Violence and symbolic } \\
\text { chaos }\end{array}$ \\
\hline Hierarchical world & Libertarian utopia & Axiological indifference \\
\hline
\end{tabular}

\section{The radicalism of the religious dimension}

A final point needs to be made. Such an extensive range of symbolic expression, including the capacity for creating disorder, hinges upon religious experience. Let us recall G. Bataille's ambitious search in eroticism for a fundamental truth of being. Without discrediting his effort, I would maintain that the erotic realm to which he refers (and which also entails violence and impurity) is, far from being autonomous, directly derived from a religious state related to his theory of sacrifice ${ }^{22}$.

When seen from a broad comparative perspective, the religious dimension seems to principally concern what does not even appear in such a structural format. The chaos discussed herein is, after all, but an example of the wellknown ganz andere (the totally other), whereby Rudolf Otto (1958) defined the sacred. I should emphasize that this 
"totally other " is not always sublime, pacific or benevolent, as suggested in so many interpretations. For example, the so-called "better" religious aspects of Afro-Brazilian religions are often defined in terms of the transcendence they provide (Roger Bastide called Candomblé a "pensée savante "). In a blatant paradox with the high degree of materiality of the symbols involved, this "better " side ends up being portrayed by some scholars as a sublimated spiritual universe that seeks to « depart from materials " (to paraphrase Walt Whitman's mystical poem So Long!). As for the marginal, « savage " and symbolically challenging side of Afro-Brazilian religiosity, it is usually seen either in terms of its political or libertarian potential ${ }^{23}$ or, on the contrary, as evidence of the allegedly underdeveloped consciousness of the cult's downtrodden participants. In this light, the exús' violence could be more or less reduced to being a reflection of the real violence existing on urban peripheries. This approach leads us out of the religious realm and turns these cults into a social institution like any other.

I would like to insist that Macumba, Quimbanda, and Jurema all use typically religious techniques for producing a proximity with chaos. One technique that keeps meanings from being rigidly set is that the pantheon is constantly expanding as new spirits with unknown and unpredictable behavior are introduced. The constant improvisation during each spirit's performance through a trance makes it very difficult to achieve dianoia (the capturing of a global meaning) and to form a coherent polysem $y^{24}$. This surprisingly continuous symbolic shift adds new complexities to established perceptions and values, and it disguises the relations between means and ends in a religious act. In my view, the obliquity of this relation keeps the dimension of the sacred alive in both the mythological field (where it expands the universe of belief and the possibilities of interpretation) and the ritual sphere (where it intensifies and diversifies body-mind experiences).

Instead of thinking about religion as a « system of symbols ", as in Clifford Geertz's (1975 : 90) famous culturalist definition, the Jurema ceremony leads us to see religious
${ }^{23}$ See, for instance, G. Lapassade and M.A. Luz's (1972) excellent interpretation of the relations between Umbanda and Quimbanda.

${ }^{24}$ See, for instance, J. Brenkman's essay (1976) on the fable of Echo and Narcissus as told by Ovid. According to J. Brenkman, Ovid's text is essentially dialogical in that it constantly destabilizes the story's meaning and opens a space of symbolic inversion analogous to what we have been considering. M. Taussig (1987) similarly subverts the classical anthropological interpretation of the religious sphere. Inspired by Artaud, among others, he criticizes V. Turner's biased association of communitas with homogeneity and unity. Following a line of reasoning that borrows heavily from $\mathrm{R}$. Caillois (1950), M. Taussig (1987 : 442) rightly argues that « by and large anthropology has bound the concept of ritual hand and foot to the imagery of order, to such an extent that order is identified with the sacred itself. ॥ 
${ }^{25}$ Readers familiar with the classics of Zen Buddhism might think of Mumonkan's case XXI : «A monk asked Unmon: "What is the Buddha?" "A shit stick", answered Unmon. » I recommend R. Blyth's brilliant commentary (1966) on this radical dialogue, which materially illustrates the symbolic deconstruction and « deangelization » proposed during Jurema ceremonies. For a relevant discussion of the crisis of representation in post-modern thought, see S.W. Foster's essay (1990) dedicated to $V$. Turner. experience as a mode of being where symbols are both signified and de-signified - both constituted and stripped of stable semantic associations ${ }^{25}$. What I have called the " third state " allows for a radical criticism and fundamental scepticism about order. It provides a sphere of action where both dominant utopias and their counterutopias (or, in Northrop Frye's words [1957], the myths both of interest and of freedom) are put aside.

Whenever there is inversion, the marginal element ends up by introducing, even if in retrograde order, the same content as the original polarity. This act, always ambivalent politically and aesthetically, rejects the predominance of established positions while, at the same time, reinforcing them. It can, therefore, be argued that a symbolic inversion invariably expresses a reaction connected to the prestige and hierarchy asserted by the dominant structure of values. As to the third state, it is an active, instead of a reactive, state of being. Understood as lying beyond inversion, it can radically rearrange established structures of meaning and embodiment. It is an operation of mental and bodily disengagement, even if temporary, from any fantasy of control and domination (again, from a political or aesthetic point of view).

The technology of these performances - what we might even call a science of ritual - provides for the presentation of chaotic configurations of both body movements and mind states. These configurations offer a glimpse of a potentially infinite generation of forms. Once consolidated into a cultural pattern, these forms operate through transformations, inversions, mimetic signs, etc. The third state precedes this consolidation. The problem of formulating such a counterintuitive notion resembles W. Benjamin's emphasis $(1977: 28)$ on presentation as discontinuity, a " renunciation of the uninterrupted course of intention".

Since this third state, understood as beyond structure and its reversal, seems to fit into a poststructuralist approach to symbolism and consciousness, this idea might be likened to J. Derrida's notion (1981) of différance, or endless dissemi- 
nation. This comparison makes sense insofar as we bear in mind that Derrida's theory is mainly a narratology. It refers to the narrating moment (always a textual recollection, even if performative in itself) of the body-mind states generated by a ritual performance and experienced by a practitioner. The third state as generated through a sacred performance seeks to bring anticipation to a halt, both in experience and in its « representation».

These issues, as previously pointed out, have received little attention. What is needed at present, besides more ethnological data concerning the diversity of these peripheral cults, is studies of the symbols of violence and disorder in Jurema and Macumba. I have yet to find, for instance, a single text featuring such deviant themes in the Catimbo songs collected by Câmara Cascudo (1951) or the Macumba songs found in the works of Arthur Ramos (1940) and Roger Bastide (1973).

Nevertheless, all evidence suggests that the number of violent, chaotic spirits is increasing. Roger Bastide and Renato Ortiz have provided sociological explanations of this. For R. Bastide (1975 : 200), the increasing presence of the "savage sacred " has to do with the transition from an organic to an anomic society whereas, for R. Ortiz (1978 : 135), these disruptive spirits express the «drama of a social stratum that is structurally excluded from participating in the values of a global society ». In other words, the number of violent spirits correlates directly with the level of violence and criminality in the lower classes.

But is such an interpretation sufficient? Sociologically, it makes sense to establish such correlations. But from the point of view of religious practices, the opposite of R. Ortiz's thesis, which R. Bastide (1978), G. Lapassade and M.A. Luz (1972) and many others have endorsed, seems more reasonable : the previously silent, marginalized classes now express their religiosity without censorship. It is one thing to discriminate symbolically and another to physically persecute Afro-Brazilian religions for being deviant. Persecution was common in Brazil until the start 
${ }^{26}$ Christian hagiography is replete with unusual anecdotes, for example, the self-inflicted violence of early Christian converts like Origen ,who ritually cut off his own genitals. Another notable example is the symbolic inversion of the figure of Saint Catherine of Siena sucking pus from a beggar's wound (Douglas, 1971). Cristiano Souza Ramos told me about a case similar to Saint Catherine's. He said he saw his father-of-saint in Brasília, possessed by a pretos-velhos spirit, cut open a large growth on a woman's neck and suck live maggots out of it. According to the fatherof-saint, the insects were there due to witchcraft.

\footnotetext{
27 It would be worthwhile to pursue this parallel with Shiva's cult, since it might lead to new insights relevant to both religious traditions. See B. Battacharya's (1975) erudite study and W.D. O'Flaherty's (1981) excellent book.
}

of the 20th century. After a long period of oppression (especially intense during colonial inquisitions in the $17^{\text {th }}$ and $18^{\text {th }}$ centuries), dominant religious values have loosened to the point of tolerating deviant forms of religious expression that, though conventionally considered as impure, irrational, grotesque or violent, deeply resonate symbolically with Christianity's history of mysticism ${ }^{26}$.

In this way, the spectrum of symbolic expressions of Brazilian religiosity has broadened to admit an extremely vibrant, complex universe where images ranging from sublime to grotesque coexist with equal intensity. The best comparison for helping us to understand this symbolic richness in more universal terms might no longer be with Christianity (which still suffers from a disenchantment of the world and from a moralization that narrows the horizon of its symbolic expression) but with other, less censured religious traditions, such as Hinduism. We might thus argue that this model of marginalized but tolerated religious behavior is not specific to African or Afro-Brazilian traditions. Pombagira's actions are not far removed from Shiva's, a god who, according to the Purana, uses eroticism and horror to break bonds, awaken those who sleep and open new spheres of contact with the numinous ${ }^{27}$. What Shiva, the great ascetic, did with unbridled, inappropriate and paradoxical eroticism, Exú and Pombagira do by means of violence, obscenity and a break with symbolic order.

Finally, il should be noted that the state of violence and chaos brought about by Jurema spirits or by the Bacchae soon turns, as if by magic, into something that is, once again, structured, intelligible and familiar. Insofar as the sacred, besides being the "totally other ", is a "tremendous mystery " as R. Otto (1958) claimed, T.S. Elliot's insightful intuition that human nature cannot bear too much reality properly applies here: Dionysus, once avenged, is satisfied and re-orders everything according to his whishes; and at dawn, the chaotic Jurema spirits leave the celebration to end in a peaceful, orderly manner. 


\section{Références bibliographiques}

Bakhtin, M.

1984 Problems of Dostoevsky's poetics, Minneapolis, Minnesota University Press.

Bastide, R.

1973 Estudos Afro-Brasileiros, São Paulo, Editora Perspectiva.

1975 Le sacré sauvage et autres essais, Paris, Payot.

1978 The African religions of Brazil, Baltimore, Johns Hopkins University Press.

Bataille, G.

1957 L'érotisme, Barcelona, Tusquets Editores.

1969 «Kali », Documentos, Caracas, Monte Ávila Editores, pp. 145-146.

1986 El culpable, Madrid, Taurus Ediciones.

1989 The tears of Eros, San Francisco, City Light Books.

Battacharya, B.

1975 Shaivism and the phallic world, New Delhi, Oxford \& IBH Publishing Co.

Benjamin, W.

1977 The origin of German tragic drama, Londres, Verso.

1986 "Critique of violence », Reflections, New York, Schocken Books.

Blyth, R.

1966 Zen and Zen classics. Volume four : Mumonkan, Tokyo, Hokuseido Press.

Botting, D. (dir.)

1979 Mysteries of the spirit cults, Rio de Janeiro/Amsterdam, Time-Life Books.

Brandão, C.R.

1986 «Festim dos Bruxos - Relações Sociais e Simbólicas na Prática do

Brenkman, J.

Curandeirismo no Brasil ", Religião e Sociedade 13(3), pp. 128-156.

1976 "Narcissus in the text ", Georgia review 3, pp. 293-327.

Caillois, R.

1950 L'Homme et le sacré, Paris, Gallimard.

Carvalho, J.J.

1988 "A força da nostalgia. A concepção de tempo histórico dos cultos AfroBrasileiros tradicionais ", Religião e sociedade 14(2), pp. 36-61.

1990a "Xangô ", Sinais dos tempos. Diversidade religiosa no Brasil, Rio de Janeiro, Instituto de Estudos da Religião, pp. 139-145.

1990b "Jurema ", Sinais dos tempos. Diversidade religiosa no Brasil, Rio de Janeiro, Instituto de Estudos da Religião, pp. 131-138.

1997 "A tradição mística Afro-Brasileira», Religião e sociedade, 18 (2), pp. 93-122.

2000 "Nietzsche and Shango : Two myths of scepticism and unveiling ", Journal of Latin American anthropology, 4(2)-5(1), pp. 238-267.

2003 "The mysticism of marginal spirits ", in Michael Pye \& Yolotl González (dir.), Religion and society, Cambridge, Roots and Branches, pp. 71-108. 
Cascudo, L. da C.

1951 Meleagro, Rio de Janeiro, Agir.

Clouzot, $\mathrm{H}$.

1951 Le cheval des dieux, Paris, René Julliard.

Contins, M. \& M. Goldman

1984 "O caso da Pombagira ", Religião e Sociedade 11 (1), pp. 103-132.

Derrida, J.

1981 Dissemination, Chicago, University of Chicago Press.

Dodds, E.

1960 Euripides' Bacchae, Oxford, Oxford University Press.

Douglas, M.

1971 Purity and danger, Londres, Pelikan.

Foster, S. W.

1990 "Symbolism and the problematics of postmodern representation", in Kathleen M. Ashley (dir.), Victor Turner and the construction of cultural criticism, pp. 117-137, Bloomington, Indiana University Press.

Frye, N.

1957 Anatomy of criticism, Princeton, Princeton University Press.

Geertz, C.

1975 "Religion as a cultural system ", The interpretation of cultures, London, Hutchinson.

Girard, R.

1998 La violence et le sacré, Paris, Hachette.

Hugo, V.

s.d. Do grotesco e do sublime, São Paulo, Editora Perspectiva.

Kirk, G.

1979 The Bacchae of Euripides, New York, Cambridge University Press.

Lapassade, G. \& M.A. Luz

1972 O segredo da Macumba, São Paulo, Pioneira.

La Porta, E.

1979 Estudo psicanalítico dos rituais Afro-brasileiros, Rio de Janeiro, Livraria Atheneu.

Leiris, M.

1958 La possession et ses aspects théâtraux chez les Éthiopiens de Gondar, Paris, Plon.

Métraux, A.

1958 Le Vaudou haïtien, Paris, Gallimard.

1963 Vodú, Buenos Aires, Sur.

Motta, R.

1977 «As variedades do espiritismo popular na Área do Recife : Ensaio de classificaçao », Boletim da Cidade do Recife, 2, pp. 97-114. 
O'Flaherty, W.D.

1981 Siva : The erotic ascetic, Oxford, Oxford University Press.

Ortiz, R.

1978 A morte branca do feiticeiro negro, Petrópolis, Vozes.

Otto, R.

1958 The idea of the holy, Oxford, Oxford University Press.

Otto, W.

1981 Dionysus : Myth and cult, Dallas, Spring Publications.

Ramos, A.

1940 O negro Brasileiro. São Paulo, Cia Editora Nacional.

Ribeiro, R.

1978 Cultos Afro-Brasileiros do Recife, Recife, Massangana.

Segal, C.

1982 Dionysiac poetics and Euripides' Bacchae, Princeton, Princeton University Press.

Segato, R.

1991 "A Tradição afro-brasileira frente à Televisão ou Duas Mortes entre a Ficção e a Realidade ", Série Antropologia, no 113 [http://www.unb.br/ics/ dan/serie_antro.htm].

1995 "Cidadania por que não ? Estado e sociedade no Brasil à luz de um discurso religioso afro-brasileiro ", Dados. Revista de Ciências Sociais, 38(3), pp. 81-601.

Souza (de), E.

1974 As bacantes de Euripedes. São Paulo, Duas Cidades.

1980 Mitologia, Brasília, Editora da Universidade de Brasília.

Stoutjesdijk, H. \& G. Glaser

s.d. About Spirits and Macumba, Rio de Janeiro, sans référence d'éditeur.

Surya, M.

1987 Georges Bataille : La mort à l'œuvre, Paris, Librairie Séguier.

Tate, A.

1952 "The symbolic imagination", Kenyon review 14, pp. 256-277.

Taussig, M.

1987 Shamanism, colonialism and the white man, Chicago, University of Chicago Press.

Trindade-Serra, O.J.

1981 "Pureza e confusão - As fontes do Limbo ", Anuário Antropológico 79,

Turner, V. pp. 48-167.

1969 The ritual process, Petrópolis, Vozes.

1975 Dramas, fields and metaphor, Ithaca, Cornell University Press.

1982 From ritual to theatre, New York, Performing Arts Journal Publications. 
Vandezande, R.

1975 Catimbó. Pesquisa Exploratória sobre uma Forma Nordestina de Religião Nordestina. Dissertação de Mestrado em Sociologia. Recife, Universidade Federal de Pernambuco.

Velho, Y.M.A.

1977 Guerra de Orisha, Rio de Janeiro, Zahar.

1984 "Resenha de O mundo invisivel ", de Maria Laura Viveiros de Castro Cavalcanti, Religião e Sociedade 11(1), pp. 163-165.

Verger, $\mathrm{P}$.

1954 Dieux d'Afrique, Paris, P. Hartmann.

1981 Orishas, São Paulo, Corrupio.

Vernant, J.P.

1988 A Morte nos Olhos. Figurações do Outro na Grécia Antiga. Ártemis e Gorgó, Rio de Janeiro, J. Zahar. 